\title{
PROCEDURAL ARBITRABILITY UNDER SECTION 301 OF THE LMRA*
}

InTERSCIEnCe Publishers, party to a collective agreement covering forty employee members of District 65, Retail, Wholesale, and Department Store Union, announced in June, 1961, its intention to merge the following October with John Wiley \& Sons, a substantially larger publishing company which was not unionized. ${ }^{1}$ It also announced that Wiley, the surviving company, would refuse to recognize the union although it was willing to hire all employees of Interscience, who would then represent a minority of the workers of the new enterprise. Inasmuch as the agreement between Interscience and the Union did not contain a clause binding the company's successors, Wiley felt secure in terminating it. Dissatisfied with a termination of the collective agreement during its life, ${ }^{2}$ and with the prospect of losing already organized employees, District 65 protested before and after the merger both to Interscience and to Wiley. When this proved unsuccessful, the Union brought suit against Wiley under the collective agreement, as provided in section 301 of the Labor Management Relations Act, ${ }^{3}$ in order to compel arbitration of the dispute. $^{4}$

The Union's protests, although strenuous, were not made in compliance with the grievance procedures established by the collective agreement. The contract required the affected employee or employees to "raise the grievance directly with the Company ... not later than four weeks after its occurrence or latest existence."5 No employee ever raised a grievance. The contract further required "that if the difference must be arbitrated, the parties make an effort to name a mutually acceptable arbitrator." ${ }^{\text {" }}$ No such effort was made. "Failure to file the grievance [in writing] within the 'time limitation' of four weeks is 'to be construed and be deemed to be an abandonment of the grievance." " Faced with this language, the district court found it "undisputed" 8 that the time limits were not met, and that "... the procedures set up by the contract for the resolution of those ... grievances were completely ignored. ..." The court never had to reach the underlying question of whether the

*John Wiley \& Sons, Inc. v. Livingston, 376 U.S. 543 (1964).

1. The statement of facts is based on Brief for Petitioner, pp. 5-15, John Wiley \& Sons, Inc. v. Livingston, 376 U.S. 543 (1964) (hereinafter cited as Brief).

2. The union was concerned with the loss of seniority of the merged employees, as well as the loss of vacation pay and employer contributions to District 65 Security Plan and District 65 Security Plan Pension Fund. Brief 11-12.

3. Labor Management Relations Act (Taft-Hartley Act) § 301, 61 Stat. 156 (1947), 29 U.S.C. § 185 (1958).

4. Livingston v. John Wiley \& Sons, Inc., 203 F. Supp. 171 (S.D.N.Y. 1962).

5. Brief at 57 .

6. Ibid.

7. Id. at 58 .

8. Livingston v. John Wiley \& Sons, Inc., 203 F. Supp. 171, 173 (S.D.N.Y. 1962).

9. Ibid. 
dislocations caused by the merger constituted an arbitrable dispute under the contract; it simply held that, as the Union had not complied with the procedural conditions precedent to arbitration established by the contract, the suit must fail.

The Union appealed to the Court of Appeals for the Second Circuit, which reversed the district court, holding, inter alia, that it was for the arbitrator, not the court, to decide whether or not a union had complied with the grievance procedures. ${ }^{10}$ The Supreme Court, on certiorari, affirmed. ${ }^{11} \mathrm{Mr}$. Justice Harlan, for a unanimous Court, in this the first Supreme Court case presenting the issue of procedural arbitrability - the question of whether a court or an arbitrator should decide all issues of compliance with the grievance procedure $^{12}$ - held that a court's role under section 301 is exhausted once it has found the substantive dispute to be arbitrable. The issue of procedural arbitrability was thus resolved by the Court in favor of the arbitrator. ${ }^{13}$

The proper meaning of section 301 of the Taft-Hartley Act, and the proper role of the federal courts in applying it, have been problems of great significance to the labor bar for several years. ${ }^{14}$ Section 301 itself simply provides that the federal courts shall have jurisdiction of suits between employers and labor unions without regard to diversity of citizenship. It contains no standards to guide the courts in deciding these suits. In 1957, the Supreme Court first gave content to section 301 by holding that a union may sue in federal court to compel an employer to arbitrate a dispute covered by the arbitration clause of the collective agreement. ${ }^{15}$ The standards to be employed in deciding

10. Livingston v. John Wiley \& Sons, Inc., 313 F.2d 52 (2d Cir. 1963). Reaching the merger question, the Second Circuit held that because an arbitrator could find the agreement survived consolidation, he should be given the opportunity to do so.

11. John Wiley \& Sons, Inc. v. Livingston, 376 U.S. 543 (1964).

12. For an introduction to procedural arbitrability see Note, Procedural Requirements of a Grievance Arbitration Clause: Another Question of Arbitrability, 70 Yale L.J. 611 (1961) ; Dunau, Procedural Arbitrability - A Question for Court or Arbitrator, 14 LAB. L.J. $1010(196: \rightarrow$ Cox, Reflections upon Labor Arbitration, 72 HARv. L. Rev. 1482, 150811 (1959).

13. The Supreme Court affirmed the Second Circuit on the merger question also, holding that "... Wiley's obligation to arbitrate this dispute [is found] in the Interscience contract, construed in the context of a national labor policy." 376 U.S. at 550-51.

14. See, e.g., Summers, Individual Rights in Collective Agreements and Arbitration, 37 N.Y.U.L. Rev. 362 (1962) ; Christensen, Arbitration, Section 301, and the National Labor Relations Act, 37 N.Y.U.L. Rev. 411 (1962); Jay, Arbitration and the Federal Common Law of Collective Bargaining Agreements, 37 N.Y.U.L. Rev. 448 (1962) ; Wellington, Judicial Review of the Promise to Arbitrate, 37 N.Y.U.L. Rev. 471 (1962); Comment, The Emergent Federal Common Law of Labor Contracts: A Survey of the Law Under Section 301, 28 U. CHI. L. Rev. 707 (1961).

15. Textile Workers Union v. Lincoln Mills, 353 U.S. 448 (1957). This case and those discussed in the text at notes 16-21 infra deal with issues of substantive arbitrability - whether or not the dispute was covered by the arbitration clause of the collective agreement. It has been persuasively argued that the task of providing standards for the guidance of the federal judiciary in this area is best done by Congress, and that therefore the Supreme Court should not have made the attempt itself. See Bickel \& Welling- 
section 301 cases were to be derived from "[our] national labor laws."16 The famed Steelworkers Trilogy, decided by the Court in 1960, added specific content to these standards. In two suits to compel arbitration ${ }^{17}$ and one to enforce an arbitrator's award, ${ }^{18}$ the following propositions were established: since arbitration is a matter of contract, a court, and not the arbitrator, should find the obligation to arbitrate in the collective agreement, and must delimit the arbitrator's jurisdiction accordingly. ${ }^{19}$ Because of the nature of the collective agreement, the special competence of the arbitrator in applying it, and the belief that arbitration will lead to industrial peace - a significant tenet of our national labor policy - the principal canon of judicial construction of labor contracts adopted by the Court was a strong presumption in favor of arbitrability: unless a dispute is specifically excluded from the grievance clause, a court should consider it included. ${ }^{20}$ Since application of the presumption in favor of arbitrability will often result in parties being compelled to arbitrate disputes not clearly intended to be subject to arbitration, the contract rationale - that arbitration is a matter of agreement between private parties will often be subordinated to this presumption. ${ }^{21}$ The degree of this subordination is exemplified by the Wiley case itself, for the Supreme Court in the initial segment of its opinion held that Wiley was obligated to arbitrate, although the company was not a party to the contract containing the arbitration clause. $^{22}$

ton, Legislative Purpose and the Judicial Process: The Lincoln Mills Case, 71 Harv. L. REv. 1 (1957); see also Mr. Justice Frankfurter's dissenting opinion in Lincoln Mills, 353 U.S. at $460-68$.

16. 353 U.S. $448,456$.

17. United Steelworkers v. American Mfg. Co., 363 U.S. 564 (1960); United Steelworkers v. Warrior \& Gulf Nav. Co., 363 U.S. 574 (1960).

18. United Steelworkers v. Enterprise Wheel \& Car Corp., 363 U.S. 593 (1960). For comment on the Steelworkers Trilogy see Hays, The Supreme Court and Labor Law October Term, 1959, 60 Colum. L. Rev. 901 (1960).

19. United Steelworkers v. Warrior \& Gulf Nav. Co., 363 U.S. 574, 582 (1960); United Steelworkers v. American Mfg. Co., 363 U.S. 564, 568 (1960).

20. United Steelworkers v. Warrior \& Gulf Nav. Co., 363 U.S. 574, 582-83 (1960).

21. As an example, in the Warrior case the union successfully sought to persuade a court to order arbitration on the question of whether the employer could contract out work. Yet the evidence was clear that in bargaining sessions the union had persistently attempted to get the employer to agree to make contracting out arbitrable, and had always failed. In an ordinary contract case this history would probably have been sufficient to induce a court not to order arbitration of the dispute, and in this case induced the district and circuit courts to find for the employer. 168 F. Supp. 702 (S.D. Ala. 1958), 269 F.2d 633 (5th Cir. 1959). Yet as contracting out was not specifically excluded from the arbitration clause in Warrior, the Court held it arbitrable.

22. At times it may be justifiable to hold a person liable on a contract he did not sign despite the principle of freedom of contract. An example is given by a New York statute which provides that a creditor will not lose a cause of action because his debtor has entered a merger and the surviving party to the merger was not a party to the contract creating the liability. N.Y. Stock Corporation Law $\S 90$; see also 15 Fletcher, Private Corporatrons $\S 7121$ (1961 rev. ed.). As the Wiley case arose in New York, the union argued that it fit under this statute, and that a holding requiring Wiley to arbitrate would 
Before analyzing the issue of which decision-maker, court or arbitrator, should adjudicate questions of procedural compliance, it should be useful to describe the kind of problems to be resolved. Essentially two questions are relevant: whether the union has complied with the procedural requirements of the contract, and if not, whether its noncompliance was excusable. Compliance cases, which form the great majority of procedural disputes, break down into three general categories: questions of timeliness; questions of who is eligible or required to file; questions where there has been no procedural compliance at all, but instead a direct request for arbitration, such as Wiley.

Timeliness. ${ }^{23}$ When Did the Violation Occur: In Twin Cities Container Corp. and United Paper Patterns and Paper Workers, Local 1929, ${ }^{24}$ for example, the collective agreement provided that all grievances must be filed within ten calendar days of the grieved event. On December 11, 1962, the employer

not be antithetical to normal contract principles. The court did not consider the argument, choosing instead to rely on federal law as a source of its holding that Wiley was required to arbitrate the questions raised by the merger. 376 U.S. at 548. But if the union fits within the policy of the New York statute the Court's result would not seem to clash seriously with contract law.

It seems clear, however, that the union was not the type of creditor envisioned by the New York statute because it did not possess an existing cause of action against Interscience at the time of the merger. A labor contract does not guarantee employment for a specific term with a cause of action arising for damages if it is terminated prior to the period it is written to cover. Collective agreements provide only that as long as an employer operates the plant in substantially the same manner as when the contract was written, he is required to abide by the standards of the agreement. Should he choose to go out of business he is only liable to the union for the time worked by union members. The collective agreement is a contract at will. When Interscience terminated its operations, the agreement also terminated, and the union had no cause of action for monies it would have received had there been no merger. It is these monies the union was trying to get. As the union cannot be regarded as a creditor in the sense that the alleged debtor, Interscience, is not liable to it for money the union would have received had the contract been fully performed, it does not fit within the policy of the New York statute. The Court's holding that Wiley was required to arbitrate under the Interscience contract is, therefore, quite contrary to established contract principles.

It may be argued that when an employer has sold his business, but the plant is operated substantially as before, there is a legitimate interest in not requiring the union to go through the entire process of renegotiating the collective agreement. The buyer ought to assume the contract for the remainder of its term. This is clearly not the situation in Wiley, however, in that the union, instead of having forty employees organized in a small plant, had, after the merger, twenty-nine employees in a much larger working force in a different plant. 376 U.S. at 545. To apply the Interscience contract to Wiley is to ignore normal contract law, and the court recognized this. "While the principles of law governing ordinary contracts would not bind to a contract an unconsenting successor to a contracting party, a collective bargaining agreement is not an ordinary contract." $I d$. at 550.

23. This is by far the most common procedural breach. For additional comment on the problems it produces see the Steelworker's Handbook on Arbitration Decisions 120-28 (1960). For a discussion of grievance procedures, see generally TROTTA, LABOR ARBitration 246-63 (1961).

24. CCH Labor Arb. Awards Rep. ๆ 8615 (1963). 
closed the plant because of a snow storm so that the employees worked three instead of the customary four hours. On the 12th of December the time cards showed that the affected employees received credit only for the hours worked. As the contract was susceptible to an interpretation that a four hour shift was guaranteed, a possible grievance was created. On December 21, the employees were paid for the period including the three hour day. The grievance was filed December 31. If the violation had occurred when the affected employees were notified that they would not be paid for a full shift, December 12 , the grievance was not filed on time; if the violation occurred when the employees were actually paid, December 21 , the filing was timely. The issue for decision was at what time the violation occurred.

Notice: The collective agreement required the union to grieve within thirty days of the alleged violation. Their complaint, the employer asserted, was filed sixteen months late. In response, the union argued that they were only required to file thirty days after they were notified of the violation, and absent notification by the employer, they complied by complaining within thirty days of their having reason to be aware of the violation. The issue involved was the meaning of "notification" under the contract. ${ }^{25}$

Continuing Violations: The employer contracted out work previously done by members in the bargaining unit. Several months after the practice began, the union filed a grievance, arguing that it was timely so long as the contracting out continued, or for twenty days after the contracting out ceased. The decision maker had to rule on whether the violation of the contract occurred when the union first knew of the contracting out, or whether it continued as long as the practice was maintained. If the latter, the grievance was timely. ${ }^{26}$

IMPROPER Filing. The preamble to the grievance section of the collective agreement provided that the section was intended to settle disputes between the employer and the employees or the union. Then followed explicit directions for how an employee should process a grievance; nothing was said of filing by the union. A dispute arose which directly affected an employee but he neglected to file a grievance. Since the dispute could have affected many other employees, the union attempted to file. The issue was whether the union could file at all, and if so, whether it did so in a reasonable manner. ${ }^{27}$

Complete Failure to Comply. The collective agreement provided that a party desiring arbitration must notify the other party in writing within twenty days of the failure of the intra-company grievance procedure. More than nine months after such a failure the union requested arbitration. In reply to the assertion of a procedural breach, the union argued that the employer's con-

25. In re Republic Steel Corp., Gadsden Plant and United Steel Workers of America, 27 BNA Labor ARb. Rep. 262 (1956) (Union filed sixteen months after the disputed practice arose).

26. In re ACF Industries, Albequerque Division and Int'1 Ass'n of Machinists, 38 BNA LABor ARb. Rep. 14 (1962).

27. National Lead Co. and United Steelworkers of America, Local 4585, CCH LABor Arb. Awards Rep. ๆ 8422 (1963). 
duct, a continual insistence that the substantive dispute was not arbitrable, estopped him from relying on the breach. Whether such conduct should be construed to estop the employer and excuse the union from performance was at issue. ${ }^{28}$

Procedural arbitrability has been a troublesome issue for the lower federal courts, and the decisions have been equally divided on the question of whether a court or an arbitrator should adjudicate the issues involved in allegations of noncompliance with grievance procedures. ${ }^{29}$ One reason for the split may have been that some courts initially did not recognize procedural arbitrability as an existing problem. Rather, courts simply decided whether or not the union had complied with the grievance provisions, and if satisfied that the union had done so, the court ordered arbitration of the substantive dispute. No attention was paid to the issue of whether the court or arbitrator should have been the decision-maker. When later the same courts discovered the issue of procedural arbitrability, they ignored prior cases and resolved the issue in favor of arbitration. A good example of this occurred in the Fifth Circuit.

28. International Ass'n of Machinists v. Hayes Corp., 296 F.2d 238 (5th Cir. 1961).

29. For the Arbitrator: Carey v. General Electric Co., 315 F.2d 499 (2d Cir. 1963), cert. granted, 32 U.S.L. WeEk 3003 (U.S. July 2, 1963) ; Local 748, IUE v. Jefferson City Cabinet Co., 52 L.R.R.M. 2513 (6th Cir. 1963) ; Deaton Truck Line v. Local 612, Teamsters Union, 51 L.R.R.M. 2552 (5th Cir. 1962) ; International Tel. \& Tel. Corp. v. Local 400, IUE, 286 F.2d 329 (3d Cir. 1961) ; Radio Corp. of America v. Association of Professional Eng'r Personnel, 291 F.2d 105 (3d Cir. 1961) ; Local 696, IBEW v. Ohio Power Co., 53 L.R.R.M. 2026 (S.D. Ohio 1963) ; Furniture Workers v. Mohawk Corp., 52 L.R.R.M. 2209 (M.D. Pa 1963) ; Philadelphia Dress Joint Bd., ILGWU v. Sidele Fashions, Inc., 187 F. Supp. 97 (E.D. Pa. 1960) ; Local 971, UAW v. Bendix-Westinghouse Automotive Air Brake Co., 188 F. Supp. 842 (N.D. Ohio 1960) ; Association of Westinghouse Salaried Employees v. Westinghouse Elec. Corp., 188 F. Supp. 225 (W.D. Pa. 1959), aff'd, 283 F.2d 93 (3d Cir. 1960) ; United Cement Workers v. Allentown-Portland Cement Co., 163 F. Supp. 816 (E.D. Pa. 1958); Wilson Bros. v. Textile Workers Union, 132 F. Supp. 163 (S.D.N.Y. 1954), appeal dismissed, 224 F.2d 176 (2d Cir. 1955), cert. denied, 350 U.S. 834 (1955) ; Insurance Agents Int'1 Union v. Prudential Ins. Co., 122 F. Supp. 869 (E.D. Pa. 1954).

For the Court: Southwestern Elec. Power Co. v. Local 738, IBEW, 293 F.2d 929 (5th Cir. 1961); International Ass'n of Machinists v. Hayes Corp., 296 F.2d 238 (5th Cir. 1961) ; Boston Mut. Life Ins. Co. v. Insurance Agents Union, 258 F.2d 516 (1st Cir. 1958), on remand, 171 F. Supp. 125 (D. Mass. 1959), aff'd, 268 F.2d 556 (1st Cir. 1959) ; Grocery \& Food Prods. Warehouse Employees Union v. Thomson \& Taylor Spice Co., 214 F. Supp. 92 (N.D. I1l. 1963) ; Truck Drivers v. Grosshans \& Petersen, Inc., 51 L.R.R.M. 2116 (D. Kan. 1962) ; Black-Clawson Co. v. International Ass'n of Machinists, 212 F. Supp. 818 (N.D.N.Y. 1962), aff'd on other grounds, 313 F.2d 179 (2d Cir. 1962) ; IBEW v. Westinghouse Elec. Corp., 51 L.R.R.M. 2133 (S.D. Ohio 1962) ; General Tire \& Rubber Co. v. Local 512, United Rubber Workers, 191 F. Supp. 911 (D.R.I.), aff'd per curiam, 294 F.2d 957 (1st Cir. 1961) ; United Brick Workers v. Gladding, McBean \& Co., 192 F. Supp. 64 (S.D. Cal. 1961) ; Drake Bakeries Inc. v. Local 50, Am. Bakery Workers, 196 F. Supp. 148 (S.D.N.Y. 1960), aff'd, 294 F.2d 399 (2d Cir. 1961), aff'd, 370 U.S. 254 (1962) ; Brass Workers v. American Brass Co., 172 F. Supp. 465 (E.D. Wis.), aff'd, 272 F.2d 849 (7th Cir. 1959), cert. denied, 363 U.S. 845 (1960) ; International Union of Operating Eng'rs v. Monsanto Chem. Co., 164 F. Supp. 406 (W.D. Ark. 1958). 
During 1961, the court, without recognizing a possibility of choice between alternate decision-makers, twice held that a union was excused from complying with grievance procedures and ordered arbitration of the substantive dispute. $^{30}$ In 1962, without mentioning its prior rulings, the circuit court decided that compliance should be determined by an arbitrator. ${ }^{31}$

Courts which have recognized the problem of procedural arbitrability and have resolved the issue in favor of judicial decision usually rely on a contract rationale. ${ }^{32}$ This contract argument is based upon the notion that the collective agreement, and only the collective agreement, confers jurisdiction on the arbitrator, even when it contains a broad arbitration clause leaving all questions of contract interpretation or application to the arbitrator. The courts have reasoned that this jurisdiction may not be exercised unless the two conditions set by the parties have been met. First, the substantive dispute has been made arbitrable by the contract; second, the condition precedent to arbitration - compliance with the grievance procedures - has been fulfilled. ${ }^{33}$ Accordingly, the court must rule on whether there was compliance with the procedural requirements of the contract, or if not, whether the breach was excusable. Of course, the parties may have agreed to let the arbitrator rule on one or both of these conditions. But unless they have done so, and that agreement can be fairly found in the contract, the courts must decide. ${ }^{34}$

Prior to Wiley, however, most courts holding procedural questions arbitrable have also claimed to rely on the collective agreement, specifically upon the standard broad arbitration clause giving the arbitrator jurisdiction over every dispute concerning the contract's interpretation or application. ${ }^{35}$ Courts then reasoned that, as the issue of procedural compliance clearly involved the interpretation or application of the agreement, the arbitrator had jurisdiction to

30. Southwestern Electric Power Co. v. Local 738, IBEW, 293 F.2d 929 (5th Cir. 1961 ) ; International Ass in of Machinists v. Hayes Corp., 296 F.2d 238 (5th Cir. 1961).

31. Deaton Truck Line, Inc. v. Local 612, Teamsters Union, 51 L.R.R.M. 2552 (5th Cir. 1962). A similar example of this phenomenon is given by the Second Circuit in holding, in the Wiley case, that procedural compliance is to be decided by the arbitrator. In so holding it overruled Black-Clawson Co. v. International Ass'n of Machinists, $212 \mathrm{~F}$. Supp. 818 (N.D.N.Y. 1962) ; and Drake Bakeries, Inc. v. Local 50, American Bakery Workers, 196 F. Supp. 148 (S.D.N.Y. 1960), on the procedural question, and did not mention either case.

32. See, e.g., Boston Mut. Life Ins. Co. v. Insurance Agents Union, 258 F.2d 516 (1st Cir. 1958) ; Brass Workers v. American Brass Co., 272 F.2d 849 (7th Cir. 1959).

33. This argument assumes that compliance with the grievance procedures is a condition precedent to arbitration. The assumption seems a correct one. See text at notes 59-63 infra.

34. The best statement of this argument is found in Judge Magruder's opinion in Boston Mut. Life Ins. Co. v. Insurance Agents' Union, note 32 supra. For comment on the opinion, $\rightarrow$ Wellington, Judge Magruder and the Labor Contract, 72 HARv. L. Rev. 1268 (1959); Note, Procedural Requirements of a Grievance Arbitration Clause: Another Question of Arbitrability, 70 YALE L.J. 611 (1961).

35. See, e.g., Radio Corp. of America v. Association of Professional Eng'r Personnel, 291 F.2d 105 (3d Cir. 1961) ; International Tel. \& Tel. Corp. v. Local 400, IUE, 286 F.2d 329 (3d Cir. 1960). 
decide it. In short, two contradictory lines of decision have stemmed from quite similar contract language.

The cases which use the broad arbitration clause to make procedural compliance arbitrable seem, however, to be in conflict with Supreme Court holdings in the analogous area of substantive arbitrability ${ }^{36}$ For example, a court could reason from a broad arbitration clause that the question of whether a particular dispute is covered by the clause also involves the interpretation or application of the agreement and is thus for the arbitrator to decide. But the Supreme Court has held that this question of substantive arbitrability must be judicially determined despite the presence of broad arbitration clauses. ${ }^{37}$ Procedural arbitrability, if viewed as a question of contract, is similar to substantive arbitrability; both involve the issue of whether the parties intended the particular dispute to be subject to arbitration. In the latter the question is whether the dispute is of the character intended to be arbitrated, while in the former the inquiry is which forum, court or arbitrator, was meant to determine questions of procedural compliance. Both issues may thus be analyzed as being concerned with the jurisdiction of the arbitrator established by the parties in their contract. If reasons were offered to distinguish the jurisdictional questions involved in procedural and substantive arbitrability, then the procedural arbitrability cases utilizing the broad clause might be reconciled with the Supreme Court cases on substantive arbitrability; however, no court has attempted to do so. Thus reasoning from a broad arbitration clause to make procedural compliance a question for an arbitrator would seem unwarranted.

In addition, it might be argued that a holding that questions of procedural compliance are arbitrable based on a broad arbitration clause is simply poor contract construction. Arbitration clauses are usually written to deal with grievances, which ". . . are almost always complaints against action taken or refused by the employer." 38 It is clear that the issues of procedural compliance do not fall within this description of the type of dispute to be heard by an arbitrator. A broad arbitration clause standing alone does not seem to be sufficient evidence for a court to conclude that the parties intended procedural questions to be arbitrable. It might be maintained, however, that the grant of power to decide grievances necessarily comprehends the power to decide whether the case is properly before the arbitrator; an arbitrator as an ad-

36. It should be noted that the terms substantive and procedural arbitrability are not analogous since they pose different issues to the court. Substantive arbitrability involves the issue of whether a given dispute was intended by the parties to be included in the arbitration clause. Procedural arbitrability requires the court to determine which decisionmaker, court or arbitrator, should determine the issue of procedural compliance.

37. "Under our decisions, whether or not the company was bound to arbitrate, as well as what issues it must arbitrate, is a matter to be determined by the Court on the basis of the contract entered into by the parties." Atkinson v. Sinclair Refining Co., 370 U.S. 238, 241 (1962).

$3 \rightarrow$ Shulman, Reason, Contract and Law in Labor Relations, 68 Harv. L. Rev. 999, 1007 (1955). See also Elkouri, How Arbitration Works 64 (BNA 1956). 
judicator should have jurisdiction to decide his own jurisdiction. The argument logically extended leads to the proposition that the parties intended the power to decide grievances to carry with it the power to decide all jurisdictional questions pertaining thereto. Parties, however, presumably contract in awareness of the law, and the law has always been that the jurisdictional issue of substantive arbitrability is not a question for the arbitrator but rather for the court. ${ }^{39}$ It seems anomalous to argue that the parties, recognizing this rule of substantive arbitrability, meant by their silence to create a different rule for procedural arbitrability. A more plausible reading of the contract would be that the arbitration clause does not speak to jurisdiction at all. ${ }^{40}$

One possible reason for the courts' ready acceptance of the contract rationale based on the existence of a broad arbitration clause is that initially it seems a plausible way to construe the contract, and, as the procedural claim has often been only one among a miscellany of contentions advanced by an employer to avoid arbitration, many courts may not have considered the issue important enough to warrant analysis in depth. A second explanation may be that courts which have relied on the broad arbitration clause have used the contract rationale to justify results reached on other grounds. Judges, for example, may have felt ill at ease deciding procedural compliance and may have preferred to leave the decision to the expertise of an arbitrator. Courts, however, are seldom reticent in the labor area to ascribe expertise to an arbitrator and remand cases to him for decision ;1 yet in questions of procedural arbitrability only one decision prior to Wiley suggested the rationale of expertise. ${ }^{42}$ It would seem that in general the courts were either unaware of the expertise argument or, for some reason, failed to articulate it.

In the Wiley case, the Supreme Court holding that procedural questions were arbitrable was rested on a policy base, and the Court placed no reliance

39. While the term substantive arbitrability is a new one, it has long been the law that courts must determine the scope of the parties' promise to arbitrate. See, e.g., United States v. Moorman, 338 U.S. 457 (1950) ; Local 149, American Fed'n' of Technical Eng'rs v. General Elec. Co., 250 F.2d 922 (1st Cir. 1957), cert. denied, 356 U.S. 938 (1958); Local 205, United Elec. Workers v. General Elec. Co., 233 F.2d 85 (1st Cir. 1956), aff'd, 353 U.S. 547 (1957). U.S. Arbitration Act, 9 U.S.C. $\S 3$ provides, inter alia, that a federal court must be "satisfied that the issue involved in such suit or proceeding is referable to arbitration under ... an agreement ...."

40. Where the contract is not explicit on the question of which decision maker was intended by the parties, a court may, of course, find through extrinsic evidence, such as established custom in the plant, that the parties nevertheless wished issues of procedural compliance to be arbitrable. Also, a court could determine from extrinsic evidence that the parties never considered the question of forums, and could then, by asking itself what the parties would have intended had they thought of the issue, find that the litigants, by indicating a preference for arbitration through the use of a broad arbitration clause, would have wanted questions of procedural compliance to be arbitrable as well. But where the contract contains only the arbitration clause, and no extrinsic evidence is introduced, it seems more probable that the parties wished a court to resolve their procedural problems.

41. See, e.g., cases cited in notes 17 and 18 supra.

42. Philadelphia Dress Joint Bd., ILGWU v. Sidele Fashions, Inc., 187 F. Supp. 97, 100 (E.D. Pa. 1960). 
on a contract analysis of the collective agreement. ${ }^{43}$ Thus, Mr. Justice Harlan did not even rely upon the presumption in favor of arbitrability, employed by the Court in its discussion of the substantive arbitrability aspect of the case, ${ }^{44}$ to support his decision on the procedural issue.

The Court's conclusion that procedural compliance was an issue for the arbitrator implicitly relied upon the presumed special competence of the arbitrator to make this type of decision. Although not clearly articulated in the Supreme Court opinion, ${ }^{45}$ the argument based on the expertise of an arbitrator may be broken down into two specific considerations. Initially, it is frequently argued that the collective agreement is quite unlike other contracts. ${ }^{46}$ First, the contract attempts to govern complex relationships for a significant period of time. It therefore must be a somewhat general document which can be completely understood only with some specialized knowledge of the general background of industrial relations against which the parties contracted. Second, collective agreements are often written in haste under pressure of a strike and in moments of high tension. It is likely they will reflect the manner of their creation, tending to be imprecise and not susceptible of easy construction. In fact, it is often the intention of the parties to be ambiguous; a conflict at the bargaining table may be resolved through the drafting of a phrase capable of varying interpretations in the hope that a dispute will not arise or will be more easily settled in the future. Lastly, there are certain areas where the parties feel that specificity is unnecessary: Dean Shulman gives the example of discipline for cause. ${ }^{47}$ All of these factors make the collective agreement a very difficult document to construe. Only an arbitrator aware of the industrial context and the character of the parties can successfully deal with the contract, and courts ought not to try.

This argument is not necessarily true in matters of procedure. Grievance provisions in collective agreements are basically the same, transcending industries and individual peculiarities. ${ }^{48}$ Essentially these provisions provide for

43. The Court felt its holding ". . . best accords with the usual purposes of an arbitration clause . . ." 376 U.S. at 559. It did not ask, however, whether it accorded with the purpose of the Interscience arbitration clause, a contention the Wiley attorney strenuously denied. See Brief for Appellant, pp. 50-62. Inasmuch as the Court did not analyze the collective agreement in the suit before it, but stated in the same sentence as the above quotation that its result also accorded with ". . . the policy behind federal labor law . .." 376 U.S. at 559, it seems clear the Court did not base its holding on the contract.

44. 376 U.S. at 550-51.

45. The opinion, as articulated, rested upon the Court's belief that as procedural questions were practically indistinguishable from substantive ones, the arbitrator should hear them. Implicit in this reasoning is the conclusion that the same considerations of expertise which the court believes apply in the substantive context, see, e.g., United Steelworkers v. Warrior \& Gulf Nav. Co., 363 U.S. 574 (1960), apply equally to issues of procedure.

46. See, e.g., Summers, Individual Rights in Collective Agreements and Arbitration, 37 N.Y.U.L. REv. 362 (1962) ; Shulman, supra note 38, at 1003-05.

47. Id. at 1006-07.

48. Ninety-four percent of collective agreements provide for arbitration. 2 BNA Collective Bargaining Negotiations and Contracts $\S 51: 7$ (1960). More than nine 
“. . . a hierarchy of joint conferences between designated representatives of the employer and the union." 49 Their sameness is explicable in terms of the purpose of these conferences. Simply, they serve to bring together at each level union and company officials of roughly similar status, such as shop steward and foreman, in order to encourage an orderly exchange of views on any dispute with the intent of settling it at that level or of clarifying the issues involved in order to ease the task of settlement for the more responsible personnel. If all else fails, the last step requires the selection of an arbitrator. The function of this procedure is not limited to any one industry, nor is it so complex as to require expert knowledge to understand and apply it.

Although the purpose of grievance procedures is simple and the procedures are superficially similar in different agreements, it may be argued that, in fact, these procedures are closely linked to specific circumstances and cannot be fully understood out of context. Yet this does not compel the selection of an arbitrator as the appropriate decision maker. For here, the collective agreements are specific. They contain explicit directives as to who should file a grievance, with whom, in what way, and by what time. They provide how long decision should take at each level, who should appeal, to whom, how and when, and how and when an arbitrator should be selected. ${ }^{50}$ When some certitude is possible and desirable unions and employers normally seek it ; ${ }^{51}$ because of the unlikelihood of strikes taking place over whether a union should file a grievance within ten or fourteen days, or whether the foreman or plant manager should first hear it, the parties can and do write relatively explicit agreements. Of course, local conditions will always be of significance in interpreting and applying the collective agreement, and a knowledge of them is helpful. But here, with the purpose of the grievance procedures so clear, and the contract itself relatively explicit, a court seems capable of coping with the procedural aspects of a grievance clause. ${ }^{52}$ The very explicitness of the pro-

out of ten agreements outline steps to be followed in adjusting grievances, with the three step procedure being the most common. Id. at $\S 51: 4$. Also, time limits for filing a grievance are frequently imposed, 2 BNA Collective Bargaining Negotiations and ConTRACTS $\S 51: 281$ (1963), and there is usually a requirement that grievances be reduced to writing. $I d$. at $\S 51: 21$. See generally ElkourI, op. cit. supra note 37; see also note 23 supra.

$4 \rightarrow$ Shulman, Reason, Contract and Law in Labor Relations, 68 Harv. L. Rev. 999, 1007 (1955).

50. A good example of a typical grievance procedure set out in a collective agreement is found in Trotta, Labor Arbitration 257 (1961).

51. Shulman, supra note 49 , at 1005.

52. It may be argued that judicial application of the contract standard will result in "standardization" not consonant with the inherently local nature of industrial government. $: \rightarrow$ Wellington, Judge Magruder and the Labor Contract, 72 HARv. L. REv. 1268, 1285 (1959). The short reply to this is that (a) the area of grievance procedures is inherently somewhat standardized; (b) if any local peculiarity of grievance procedure is important to the parties, it can easily be written into the agreement; and (c) even if not in the contract, such local custom can be urged upon the court as extrinsic evidence modifying the written agreement. 
cedural clauses would, moreover, seem to preclude the utilization of a second form of competence often attributed to arbitrators - the ability to act as a constructive policy maker free to find a creative solution in those areas where the result is not provided in the contract. ${ }^{53}$

A second facet of the expertise argument is suggested by the Supreme Court in the Wiley opinion. Justice Harlan felt that finding a procedural breach on the part of the union would not of itself end the matter; the decisionmaker must then decide whether the breach ought to cut off totally the union's right to arbitration or should instead be reflected in the arbitration award. ${ }^{54}$ A decision-maker faced with a question of reinstatement could, for example, find a procedural breach, decide to reach the merits despite it, and qualify or structure the award to reflect the breach by granting less back pay than the employee would have received had there been procedural compliance. The Court felt that as the arbitrator alone could grant flexible remedies, a judge would have to remand a case to the arbitrator whenever such structuring was desirable. As structuring is likely to be desirable in most instances, ${ }^{55}$ the great majority of cases would be sent to arbitration despite procedural breaches. Justice Harlan thus concluded that a court ought not to decide procedural questions since it would be unable to provide a satisfactory remedy. In addition, the duplication of effort which would result if the court and arbitrator both adjudicated questions concerning a breach was thought unnecessary and undesirable. The argument rests on two premises: awards should be structured, and courts ought not to structure.

If the union's obligation to comply with the grievance provisions is deemed promissory, the Court's first premise is clearly correct under traditional contract analysis. The breach of a promise will give rise to an action in damages; but unless a promise goes to the essence of the contract, its breach will not relieve the other party from performance. ${ }^{56}$ Should the promise to arbitrate be independent from the promise to comply with the grievance procedure, a breach of the latter will not necessarily defeat the right to arbitration, unless the breach made arbitration useless or impossible. ${ }^{57}$ But if the obligation to comply is considered as a condition precedent to arbitration, failure to comply will absolutely defeat the union's right to arbitration in the absence of waiver

53. "The labor arbitrator's source of law is not confined to the express provisions of the contract ...." United Steelworkers v. Warrior \& Gulf Nav. Co., 363 U.S. 574, 581 (1960), and the parties choose him because of "their trust in his personal judgment to bring to bear considerations which are not expressed in the contract as criteria for judgment." $I d$. at 582. For a criticism of the Supreme Court's view of the arbitrator's function, $\rightarrow$ Hays, The Supreme Court and Labor Law October Term, 1959, 60 Colum. L. Rev. 901, 931-32 (1960).

54. 376 U.S. at $557-58$.

55. Ibid.

56. Tichnor Bros. v. Evans, 92 Vt. 278, 102 At1. 1031 (1918) ; Pinches v. Swedish Evangelical Lutheran Church, 55 Conn. 183, 10 Atl. 264 (1887).

57. Cf. Lee v. Casualty Company of America, 90 Conn. 202, 96 Atl. 952 (1916); Hammond v. Niagara Fire Ins. Co., 92 Kan. 851, 142 Pac. 936 (1914). 
or estoppel on the part of the employer. ${ }^{58}$ The issue then is whether the obligation to comply with the grievance procedures is promissory or conditional, for if it is the latter no structuring of the remedy will be possible.

Whether an obligation is promissory or conditional depends on the intention of the parties as expressed in the collective agreement and the circumstances surrounding its formation and application. ${ }^{59}$ At times, collective agreements are quite specific. If the obligations spelled out in the grievance provisions are followed by language stating that failure to follow them will be an absolute bar to arbitration, it is very difficult to resist the conclusion that these obligations are conditional. This language was present in the Wiley agreement, ${ }^{60}$ as in other collective agreements, ${ }^{61}$ but was given no effect by the Court. The Court's ignoring of the absolute bar term seems unjustified since the phrase itself may be superfluous in most collective agreements. It does not seem reasonable to assume that the parties created an intricate and specific grievance procedure, and at the same time intended that the union could easily avoid it simply by requesting arbitration directly. If the obligation were promissory this would be the case, and the employer's only remedy would be on the promise, a remedy which is often hollow, since little or no damages flow from the union's breach. ${ }^{62}$ On the other hand, it would seem consistent with the probable intention of the parties - in the absence of specific language to the contrary - to read grievance provisions as conditions precedent. Arbitrators and courts, moreover, are virtually unanimous in holding that procedural breaches totally defeat the right to arbitrate unless they are de minimis or there is estoppel. ${ }^{63}$ Since the premise that awards should be structured flies

58. 5 Williston, Contracts $\$ \S 663,675$ (3d ed. 1961); 3A Corbin, Contracts $\S 633$ (1960); see also note 40 supra.

59. 5 Williston, Contracts $\S 663$ (3d ed. 1961); see generally Corbin, Conditions in the Law of Contract, 28 YALE L.J. 739 (1919).

60. See text at note 7 supra.

61. See, e.g., United Brick Workers v. Gladding, McBean \& Co., 192 F. Supp. 64 (S.D. Cal. 1961), where the contract stated that a failure to comply with any provision of the grievance procedure "shall render the grievance void." Id. at 65 .

62. A reduction in the union's damages, traceable to its delay in filing the grievance, might occasionally be appropriate. In such a case the arbitrator, if he decides to hear the grievance in spite of its lateness (as for example where the employer's violation is deemed "continuing"), will ordinarily limit damages to the contractual time period for filing the grievance. For example, if the time limit for filing is twenty days, the union can get only twenty days back pay. See, e.g., Sears, Roebuck \& Co., and Local 1207, Retail Clerks Ass'n, 39 Lab. Arb. 567 (1962) ; Bethlehem Steel Company and United Steelworkers of America, 23 Lab. Arb. 538, 540 (1954).

63. Brass Workers v. American Brass Co., 272 F.2d 849 (7th Cir. 1959), cert. denied, 363 U.S. 845 (1960) ; Black-Clawson Co. v. International Ass'n of Machinists, 212 F. Supp. 818 (N.D.N.Y.), aff'd on other grounds, 313 F.2d 179 (2d Cir. 1963); Bonney Motor Express, Inc. and International Brotherhood of Teamsters, 40 Lab. Arb. 1019 (1963) ; H.K. Porter Company, Inc. and United Brick Workers, Local 600, 63-2 CCH Lab. Arb. If 8791 (1963); Wheeling Pipe Line, Inc. and International Bhd. of Teamsters, 63-2 CCH Lab. Arb. \ 8679 (1963) ; Truitt Mfg. Co. and International Ass'n of Bridge Workers, Local 729, 27 Lab. Arb. 157 (1956). This unanimity may reflect more 
in the face of the parties' intent as expressed in the contract, courts can award the only proper remedy in the procedural context - dismissal of the union's complaint.

An additional justification used by the Court to support its holding that procedural compliance was for the arbitrator was that, as procedural questions were so closely linked with the merits of the substantive disputes, for a court to decide issues of procedure would be to divide artificially and unnecessarily a dispute which should be treated as a whole. ${ }^{64}$ Accordingly, the Court remanded the procedural question to the arbitrator apparently in the belief that his expertise rendered him better able to provide informed judgment on the intertwined issues of procedure and substance. ${ }^{65}$ Yet the question of procedural compliance seems distinct from and unrelated to the merits of the substantive dispute. Whether or not the union had notice of an alleged violation, whether or not the employer's conduct excused the union from procedural compliance, or how to measure the allowable filing period in cases of purported continuing violations all seem to have no bearing on the underlying arbitrable substantive questions. Indeed, even in the context of the somewhat unique substantive arbitrability problems presented by the Wiley merger, issues of procedural compliance are still clearly separable from the substantive merits. The inquiry is simply as to the scope of the grievance provisions. This last point may be expanded. Assume a collective agreement provides for a complaint to the foreman as the first step in the grievance procedure. The employer decides to contract out a great deal of his work, and the union protests directly to him. When this is unsuccessful the union seeks to arbitrate. In response to an objection by the employer that the union failed to comply with the grievance provisions, a decision-maker could find that the dispute involved a matter of high company policy, that the foreman's decision could be of no help to the union, and that procedural compliance in this instance was unnecessary - the grievance provisions were simply not intended to cover this type of dispute, although the dispute itself may be arbitrable. So too in Wiley the Court could have found that the grievance provisions were not intended to resolve merger problems, and therefore the union's non-compliance was excusable. But in our hypothetical and in Wiley it is quite clear that a resolution of the procedural compliance question does not require a decision on the substantive merits - whether the employer could contract out, or whether merger terminated the collective agreement. It appears likely that in most

than respect for the principle of freedom of contract. Because of employer resistance and the nature of an arbitration award it may be quite impractical to structure awards to reflect procedural non-compliance.

64. 376 U.S. at $557-58$.

65. If the dispute was susceptible of being treated as a whole, the Court could have avoided the artificial division mentioned in the text by deciding the entire case itself. The fact that the Court did not do so indicates a belief that considerations similar to those which impelled it to remand the substantive dispute to arbitration apply to procedural questions as well. One of these considerations is that of expertise. See note 45 supra. 
situations the procedural question is separable from the merits, and courts need not get involved in the latter when they decide the former. It still might be argued that even if procedural and substantive issues are severable, the special competence of the arbitrator would make him the most appropriate decision-maker in the procedural area. However, since the contract because of its explicitness plays a predominant role in the procedural area, and since courts seem capable of properly applying it, considerations of the arbitrator's presumed competence lose much force. ${ }^{.68}$

The Supreme Court in Wiley offered a third reason for sending procedural questions to an arbitrator. It felt that requiring a judicial decision would unnecessarily delay the arbitration process. ${ }^{67}$ Allowing the parties to litigate procedural matters in court would provide them with the opportunity to "fractionate" 68 disputes in which the substantive issue was clearly arbitrable by litigating the procedural and substantive issues in separate forums. Such fractionation, the Court felt, would only cause extensive delay and unnecessary costs. ${ }^{69}$ But disputes are equally "fractionated" when procedural compliance is undisputed and the issue is substantive arbitrability. Indeed, as the great majority of cases involve issues of substantive arbitrability, the Court's argument should apply with much greater force in the substantive area. Yet Justice Harlan explicitly reaffirmed Wiley's right to demand a judicial determination of all issues of substantive arbitrability.70

By deciding Wiley through reliance on a policy analysis, the Supreme Court, in effect, created a rule of law that questions of procedural compliance are always arbitrable. It might be argued, however, that the holding in Wiley should not be read to create such a per se rule. The Court may not have envisaged a case. where the contract clearly stated that procedural compliance is to be judicially determined; faced with this explicit language the Court would, of course, decide the procedural question itself. Wiley, therefore, might be read as similar to the Steelworkers Trilogy which developed the presumption in favor of arbitrability. But this view of the actual effect of Wiley overlooks

66. See text at note 53 supra.

67. 376 U.S. at 558.

68. Id. at 559 .

69. Id. at 558-59.

70. In deciding Wiley the Court apparently was most concerned with evaluating the relative merits of courts and arbitrators as adjudicators of procedural compliance. But in its discussion the Court failed to recognize the policy consideration that the efficacy of arbitration is usually thought to depend upon the consent of the parties. $s \rightarrow$ Shulman, Reason, Contract and Law in Labor Relations, 68 HARv. L. Rev. 999, 1023-24 (1955); see also Elkouri, How Arbitration Works 66-68 (1956). It is thus argued that an arbitrator can perform most satisfactorily when he is conforming to the role designed for him by the parties in the collective agreement. Ibid. $\rightarrow$ Wellington, Freedom of Contract and the Collective Bargaining Agreement, 112 U. PA. L. REv. 467, 491 (1964). Therefore, when a court defines the arbitrator's role instead of allowing the definition to be made by the parties, it is not likely that the arbitral process will work satisfactorily and, hence, not likely that arbitration will achieve the goals the Supreme Court envisioned for it. 
the fact that the absence of all presumptive language in Wiley makes the opinion incline even more strongly toward arbitration than the Trilogy. The Steelworkers' presumption may be rebutted by a showing of intent, but faced with the Court's language in Wiley it would seem that a party not only must demonstrate a clear intent to have a court decide procedural compliance, but also must overcome the precedential weight of the Wiley holding, which is not restricted to the particular facts but is phrased generally. Moreover, given the strength of the Trilogy presumption as it is applied by the Supreme Court, ${ }^{71}$ a holding which moves beyond the presumption would seem to have an effect indistinguishable from a rule of law. Finally, a clear declaration that procedural compliance is for the courts to determine is unlikely to be written into most collective agreements. Bargaining for an explicit clause directing courts to adjudicate a portion of the contract is likely to be a divisive issue in negotiation given the typical union fear of judicial intervention in the labor area. ${ }^{72}$ Since issues of procedural compliance are only remote contingencies when bargaining occurs, a request for an explicit provision involving the federal courts will probably not be made.

Read as creating a rule of law, the Supreme Court decision in Wiley seems to ignore the language of section 301 . While section 301 is only a grant of jurisdiction to the federal courts to hear suits brought under collective agreements, it would seem that the section obligates the courts to decide all such suits. ${ }^{73}$ By announcing that procedural compliance is always for the arbitrator, the Supreme Court has, in effect, stated that it will no longer adjudicate this class of disputes arising within the ambit of the language of section 301. It seems unusual, moreover, for a court with a clear grant of jurisdiction to refuse to decide a class of disputes not because of traditional policies of judicial restraint, such as mootness, justiciability, or ripeness, but because of a belief that another decision maker would be more competent. ${ }^{74}$ This can be illus-

71. $: \rightarrow$ note 21 supra.

72. This fear is exemplified by the traditional union opposition to use of the labor injunction, see Frankfurter \& Greene, The Labor InJunction 52 (1930); cf. Winter, Labor Injunctions and Judge-Made Labor Law: The Contemporary Role of NorrisLaGuardia, 70 Y ALE L.J. 70, 71-76 (1960), an opposition which is strong tod $\rightarrow$ Wellington \& Albert, Statutory Interpretation and the Political Process: A Comment on Sinclair v. Atkinson, 72 Yale L.J. 1547, 1565 (1963).

73. The relevant portion of the statute provides, "Suits for violation of contracts between an employer and a labor organization ... may be brought in any district court ...." $\S 301$ (a), 61 Stat. 156 (1947), 29 U.S.C. § 185(a) (1958). It seems implicit in the language employed that any suit on a labor contract properly brought in a district court must be decided by that court. Since it is ridiculous to argue that a suit may be brought but not decided, a contrary interpretation of the section than that reached in the text would be that some suits for violation of contracts may not be brought in any district court. As the section provides no guides for which suits may or may not be brought, and as it seems phrased to allow all such union-employer actions, reading it to allow the courts to refuse to hear some of them appears a strained interpretation of the language Congress used.

74. When courts refuse to decide cases on the ground that they involve political questions, they are, in effect, remanding the parties to the political process. But this kind of 
trated by imagining the reception a state court would receive if, in a traditional contract action, it remanded the parties to commercial arbitration under penalty of contempt of court and without reference to their agreement because an arbitrator was thought more competent to render decision and because such remand might produce other administrative efficiencies.

Although the Wiley decision thus seems to disregard the language of section 301, support for the Court's holding can be sought in the basic policy objective of the Labor Management Relations Act, that of achieving industrial peace. $^{75}$ As it is often thought that arbitration produces industrial peace, ${ }^{76}$ it might be argued that the Court properly construed section 301 in Wiley to effectuate this goal ${ }^{77}$ by forcing the parties to arbitrate questions of procedural compliance. But it has been persuasively argued that the quest for industrial peace through arbitration is a futile one. Forcing the parties to arbitrate deeply felt grievances they did not agree to arbitrate will not prevent conflict but only transfer it from the period during the contract to the time when the contract expires. ${ }^{78}$

There is, moreover, a more fundamental objection to reading section 301 to favor arbitration because it prevents industrial strife. Such a reading seems to be contrary to the scheme of the Labor Management Relations Act itself. Congress was deeply concerned with industrial peace, to be sure, but in seeking to achieve this goal it created an explicit regulatory scheme. One major method by which Congress sought to achieve industrial peace was through the creation of a system of unfair labor practices administered by the NLRB which placed limitations on the use of economic force by employers and unions. More relevant in the Wiley context is the second major congressional strategy for achieving industrial peace, the duty to bargain in good faith embodied in section 8 (a) (5). ${ }^{79}$ In other contexts the Supreme Court has construed section 8(a) (5) as limiting the role of the NLRB and the federal judi-

remand is unaccompanied by compulsion; the parties do not have to lobby in a legislature or else face contempt of court. In Wiley, the parties must go to an arbitrator or go to jail, and it is this fact that makes the Court's remand to another institution so unusual.

75. Congress found that "Industrial strife ... interferes with the normal flow of commerce [and] ... in order to promote the full flow of commerce ..." 61 Stat. 136 (1947), passed the Labor Management Relations Act of 1947

76. Justice Douglas described arbitration as "the substitute for industrial strife," and argued that it was "a major factor in achieving industrial peace." United Steelworkers v. Warrior \& Gulf Nav. Co., 363 U.S. 574, 578 (1960).

77. The Court did not specifically mention industrial peace as a factor underlying its holding on procedural arbitrability. But it was clearly a factor in the holding, dealing with substantive arbitrability, 376 U.S. at 549, and seems to run through the entire opinion. And in so far as the Court remanded issues of procedural compliance to the arbitrator because it thought them indistinguishable from substantive questions, the industrial peace basis of the substantive holding was probably meant to apply as well to the ruling on procedure.

78. $: \rightarrow$ Wellington, Freedom of Contract and the Collective Bargaining Agreement, 112 U. PA. L. Rev. 467, 490-92 (1964).

79. 61 Stat. 141 (1947), 29 U.S.C. § 158(a) (5) (1958). 
ciary to ascertaining whether the parties in fact bargained in good faith. ${ }^{80}$ The Court has consistently maintained that Congress did not desire the NLRB or the federal courts to write the substantive terms of the agreement for the parties; section 8(a) (5), the Supreme Court has repeatedly said, institutionalizes a congressional policy judgment that freedom of contract is desirable in the industrial context. ${ }^{81}$ To the extent that $W$ iley fails to respect the intent of the parties concerning adjudication of questions of procedural compliance, the Court's interpretation of section 301 conflicts with the congressional policy of freedom of contract expressed in section $8(\mathrm{a})(5)$. Nor does the legislative history of section 301 afford any inference that Congress intended the section to affect this principle of freedom of contract. ${ }^{82}$ In fact, when Congress wished to limit the parties' right to contract freely in other contexts, it did so explicitly. As an example, Congress prohibited the parties from contracting on the subject of "hot cargo" clauses. ${ }^{83}$ Finally, the policy of freedom of contract seems particularly appropriate in the arbitration context. ${ }^{84}$ The grant of power to the arbitrator reflects the relative bargaining power of the parties, their trust in the arbitration process and their previous experience with it, the nature of the employer's business, and the collective bargaining history in the plant. It is unlikely that a court is more competent than the parties to strike a balance among these factors. The history of judicial involvement in labor relations suggests that courts should not try to formulate labor policy in this manner. ${ }^{85}$ But this is the role the Supreme Court has assumed by deciding independently of the contract which issues the arbitrator should hear.

Alan Schwartz†

80. See, e.g., NLRB v. Insurance Agents Union, 361 U.S. 477 (1960); Local 24, Int'l Bhd. of Teamsters v. Oliver, 358 U.S. 283 (1959); NLRB v. American Nat'l Ins. Co., 343 U.S. 395 (1952).

81. ". . . Congress intended that the parties should have wide latitude in their negotiations, unrestricted by any governmental power to regulate the substantive solution of their differences." NLRB v. Insurance Agents' Union, 361 U.S. 477, 488 (1960). For an analysis of the Supreme Court's holdings on freedom of contract and the duty to bargain, see Wellington, supra note 78; $\rightarrow$ Cox, The Duty to Bargain in Good Faith, 71 Harv. L. Rev. 1401 (1958).

82. The legislative history of $\S 301$ is collected in an appendix to Mr. Justice Frankfurter's dissenting opinion in Textile Workers Union v. Lincoln Mills, 353 U.S. 448, 485 (1957). It clearly reveals that Congress considered none of the problems which have arisen in this area since the Lincoln Mills case. See note 15 supra.

83. 73 Stat. 543 (1959), 29 U.S.C. 158 \& 8(e) (Supp. IV, 1964).

84. Wellington, supra note 78 , at $494-98$.

85. See generally Frankfurter \& Greene, The Labor Injunction (1930); Winter, Labor Injunctions and Judge-Made Labor Law: The Contemporary Role of NorrisLaGuardia, 70 YALE L.J. 70 (1960).

tLL.B. 1964, Yale University. 